\title{
EFFECT OF MOLASSES ON CULTIVATION OF OYSTER MUSHROOM (Pleurotus osrteatus) ON DIFFERENT AGRO- INDUSTRIAL WASTES
}

\author{
Afify, Aida H. ${ }^{*}$; M. M. A. El-Sawah ${ }^{*}$; M. S. Ali** and \\ N. K. Abd El-Rahman* \\ * Microbiology Dept., Fac. Agric., Mansoura Univ., Mansoura, Egypt. \\ ** Microbiology Dept., National Res. Center, Douki, Cairo, Egypt.
}

\begin{abstract}
For cultivation mushroom (Pleurotus ostreatus) four agro-industrial wastes namely Rice straw (RS), sawdust (SD), waste paper (WP) and cardboard industrial $(\mathrm{Cl})$ were used. Molasses $(\mathrm{M})$ can be used as a main energy source and addition of $5 \%$ molasses fo the substrates to improve the mushroom growth, yield and biological efficiency. Results regarding to the time required for completion of spawn running, pinheads and fruiting bodies formation. The spawn running, pinheads and fruiting bodies formation were found within the period ranged from 12 to 25 . from 22 to 52 and from 25 to 55 days respectively. When added molasses to the substrates the spawn running, pinheads and fruiting bodies formation were found within the period ranged from 10 to 22, from 20 to 47 and from 24 to 52days respectively. The rice straw treatment containing $5 \%$ molasses gave the maximum mushroom yield $(717.5 \mathrm{~g}$ per 1 $\mathrm{kg}$ dry substrate). Waste paper (WP) gave minimum mushroom yield (112.14g). The highest percentage of biological efficiency was obtained on molasses rice straw treatment $71.75 \%$. Low percentage of biological efficiency were found in WP $(11.21 \%)$. Molasses significantly increased the biological efficiency over control substrates.

Keywords :Pleurotus ostreatus, Agro-industrial wastes, Molasses, Cardboard industrial.
\end{abstract}

\section{INTRODUCTION}

Cultivation of edible mushrooms is a biotechnological process for lignocellulosic organic waste recycling. It might be the only current process that combines the production of protein-rich food with the reduction of environmental pollution (Beetz and Kustudia, 2004). The oyster mushrooms of the genus Pleurotus are the third largest commercially cultivated mushroom in the world. Many species of Pleurotus are commonly grown on a wide range of lignocellulosic materials. Some experiments with the agricultural wastes studied as substrates for Pleurotus spp. The substrates used in each region depend on the locally available agricultural wastes. It was also observed that the agricultural wastes of substrates used for cultivation of Pleurotus spp. could hardly promote the nutrient composition of the fruiting bodies (Ragunathan and Swaminathan, 2003).

Molasses has high carbohydrates such as sucrose, glucose and fructose. It seems that the carbon source is more necessary as an energy source than protein sources for fruiting formation. Molasses can be used as a main energy and nutritional source in the formulation of a substrate for cultivating oyster mushroom (Yang et al., 2003). 
Afify, Aida H. et al.

Previous research has shown great potential for using some lignocellulosic materials as raw material for the production of $P$. ostreatus. However, every kind of lignocellulosic substances is likely be used as substrate for Pleurotus spp. cultivation, the main and co-substrate differ among countries and even regions on the basis of availability and cost.

This study was carried out to cultivation of oyster mushroom ( $P$. ostreatus ) on different waste materials in Dakhlia, Mansoura city, Egypt, in this study orde to the effects of the agro-industrial wastes, rice straw (RS), sawdust (SD), waste paper (WP) and cardboard industrial (Cl) as substrates on spawn running time, pinheads formation, fruiting bodies formation, yield and biological efficiency (BE). Molasses addition to the substrates effects on growth and yield.

\section{MATERIALS AND METHODS}

\section{Pleurotus osrteatus :}

The sorghum spawns of $P$. ostreatus was obtained from Mushroom Unit, National Research Center (NRC), Douki, Cairo, Egypt.

\section{Sugar cane molasses :}

The sugar cane molasses was obtained from Hawamdia company for the manufacture of Sugar and Integrated Industries - Hawamdia, Giza, Egypt.

Table 1 : Chemical analysis of sugar cane molasses.

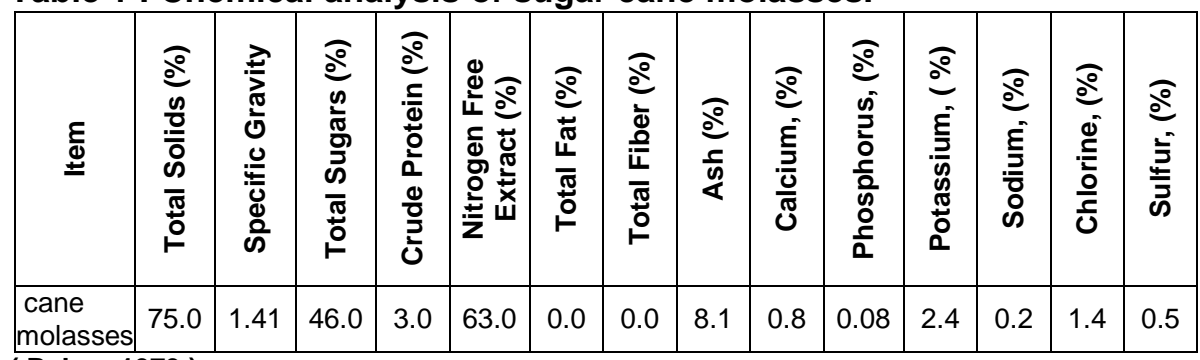

(Baker, 1979)

\section{Substrate preparation and cultivation condition :}

Rice straw (Oryza sativa), sawdust, waste paper of Handmade paper industries and cardboard industries were used as a base substrates. These substrates were chopped into small pieces of $2-5 \mathrm{~cm}$. Rice straw (RS) and Sawdust (SD) were soaked in water for 24 hour before use. Waste paper (WP) and Cadboard industries (Cl) were soaked in hot water for 3 hour to remove dyes before use. But mushrooms have ability to degrade dyes (Espindola et al., 2007).All substrate were boiled for $15-20$ minutes and then spread over clean. Slightly surface in thin layers for cooling and draining of the excessive water.

The substrate types of lignocellulosic materials were prepared by addition the molasses to each type of substrate at the concentration of $5 \%$ $(\mathrm{w} / \mathrm{w})$. 
Plastic bag technology was used in production experiments. Substrates were spawned at a rate $4 \%$ of sorghum spawn (w/w). Each bag was closed with a plastic neck. The spawned bags were then incubated at $25-30{ }^{\circ} \mathrm{C}$ and $60-65 \%$ relative humidity for $2-3$ weeks in a well-ventilated, semi dark room until spawn run was completed (El-sawah, 2000).

\section{Cropping :}

After a complete spawn run, the bags were opened after 2 weeks in case with waste paper and cardboard, 3 weeks for rice straw and 4 weeks for sawdust, when the mycelium had completely covered the substrate. The compact mass of the substrate and mycelium was watered daily with distilled sterilized water from the second day of opening of the bags. Within $3-8$ days of opening, pin head fruiting bodies $(4-5 \mathrm{~cm}$ in diameter) appeared on all sides of the bag. These young mushrooms attained the normal size in about 3 - 5 days when the first crop was harvested from each of the bags. Mature fruiting bodies were harvested at different periods and the fresh weight recorded immediately after the harvest. The time taken for the spawn running and appearance of pin heads was also recorded. Biological efficiency (BE) was calculated as percentage yield of fresh mushroom fruiting bodies in relation to dry weight of the substrate. It was necessary to calculate percentage biological efficiency because certain substrates were denser than others.

Statistical analysis :

Statistical analysis of data was carried out according to SPSS 10 for Windows ( SPSS, 1999) using LSD test to compare between mean values.

\section{RESULTS AND DISCUSSION}

\section{Growth Pleurotus spp. on different substrates :}

The growth of oyster mushroom (Pleurotus ostreatus) on tested different agro-industrial wastes, namely rice straw, sawdust, waste paper and cardboard industrial was observed.

Spawn running :

The spawn running, pinheads formation and fruiting bodies formation are three important phases in the cultivation of oyster mushroom, require proper humidity and temperature. Temperature $25^{\circ} \mathrm{C}$ for spawn running and $17-20$ ${ }^{\circ} \mathrm{C}$ for fructification showed good results (Shah et al., 2004). The mycelium totally colonized the tested agro-industrial wastes in 12.00 to 25.50 days. The shortest spawn running period was determined as average 12.00 days on waste paper, cardboard and the longest was 25.50 days on sawdust (Table 2).

\section{Pinheads formation:}

The pinheads formation is the second stage of mycelial growth during cultivation of mushroom. Small pinheads like structures were observed, (Shah et al., 2004). The substrate had valuable effect on the duration to pinheads formation. The pinheads of $P$. ostreatus started appearing $3.50-$ 39.75 days after spawn running, rice straw pinned in 22.00 days, sawdust 
pinned in 31.00 days, waste paper pinned in 48.25 days and cardboard took a longer time to pinned 52.25 days (Table 2 ).

Fruiting bodies formation:

The fruiting bodies formation are the third and final stage during the cultivation of mushroom. Agro-industrial wastes tested were different in suitability for oyster mushroom ( Pleurotus spp.) cultivation. The agroindustrial wastes had valuable effects on fruiting bodies formation. The fruiting bodies of $P$. ostreatus appeared $3.00-6.75$ days after pinheads formation and took $25.00-55.00$ days later after spawning. Rice straw and cardboard took a shorter time to fruiting bodies formatted in 3.00 days after pinheads formation. Waste paper took a longer time to fruiting bodies formatted in 6.75 days after pinheads formation, cardboard took a longer time to fruiting bodies formatted in 55.00 days later after spawning (Table 2).

The results are in agreement with those reported by Mandeel et al., (2005) and Kulshreshtha et al., (2010) in their cultivation of oyster mushroom (Pleurotus spp.) on various lignocellulosic wastes and bioremediation of industrial waste.

Tabel 2: Days completion of spawn running, pinheads and fruiting bodies formation of $P$. ostreatus at $25-30^{\circ} \mathrm{C}$ on different substrates.

\begin{tabular}{|l|c|c|c|}
\hline \multicolumn{1}{|c|}{ Substrates } & $\begin{array}{c}\text { Spawn running } \\
\text { (days ) }\end{array}$ & $\begin{array}{c}\text { Pinheads formation } \\
\text { (days) }\end{array}$ & $\begin{array}{c}\text { Fruiting bodies } \\
\text { formation (days) }\end{array}$ \\
\hline Rice straw & 18.50 & 22.00 & 25.00 \\
\hline Sawdust & 25.50 & 31.00 & 35.50 \\
\hline Waste paper & 12.00 & 48.25 & 52.00 \\
\hline Cardboard industrial & 12.50 & 52.25 & 55.00 \\
\hline
\end{tabular}

\section{Effect of molasses on growth :}

Molasses has been reported to stimulate growth many microorganisms. Molasses provides sugar, nitrogen source and other nutrients, that results in better cell growth ( Erkel. 2009). Molasses can be used as a main energy source and addition of $5 \%$ molasses to the substrates improved mushroom growth rate. Molasses addition to the substrates had valuable effect on the spawn running, pinheads formation and fruiting bodies formation. Results revealed that only $5 \%$ molasses significantly effect on cultivation oyster mushroom, the obtained results are recorded in ( Table 2 ).

When cultivation $P$. ostreatus the mycelium totally colonized the tested agro-industrial wastes and added $5 \%$ molasses in $10.50-22.50$ days. The pinheads started appearing $3.00-35.50$ days after spawn running. The fruiting bodies formation appeared 4.50 days after pinheads formation and took 24.50 - 52.00 days later after spawn running (Table 3). Molasses significant reduce in spawn running period of $P$. ostreatus over control substrates at rate $1.5-3$ days ( Fig. 1 ). Therefore reduce pinheads formation period and fruiting bodies about $2-4.75$ and $0.5-4$ days respectively. 
This results are in agreement with those reported by Erkel, (2009) in their Yield performance of Ganoderma lucidum (Fr.) Karst cultivation on substrates containing different protein and carbohydrate sources. These findings confirms with some authors who reported that molasses has stimulative growth the mycelial. When the $1 \%$ of various sugars were added to PDA plates, the highest mycelial growth was found on the plate with molasses addition (Paterrson-Beedle et al., 2002, Hsieh et al., 2005).

Table 3. Effect of molasses on the growth of $P$. ostreatus at $25-30{ }^{\circ} \mathrm{C}$.

\begin{tabular}{|l|c|c|c|}
\hline $\begin{array}{c}\text { Substrates containing } \\
\mathbf{5} \% \text { molasses }\end{array}$ & $\begin{array}{c}\text { Spawn running } \\
\text { (days })\end{array}$ & $\begin{array}{c}\text { Pinheads formation } \\
\text { (days) }\end{array}$ & $\begin{array}{c}\text { Fruiting bodies } \\
\text { formation (days) }\end{array}$ \\
\hline Rice straw & 17.00 & 20.00 & 24.50 \\
\hline Sawdust & 22.50 & 27.00 & 31.50 \\
\hline Waste paper & 10.50 & 45.50 & 50.00 \\
\hline Cardboard industrial & 11.00 & 47.50 & 52.00 \\
\hline
\end{tabular}

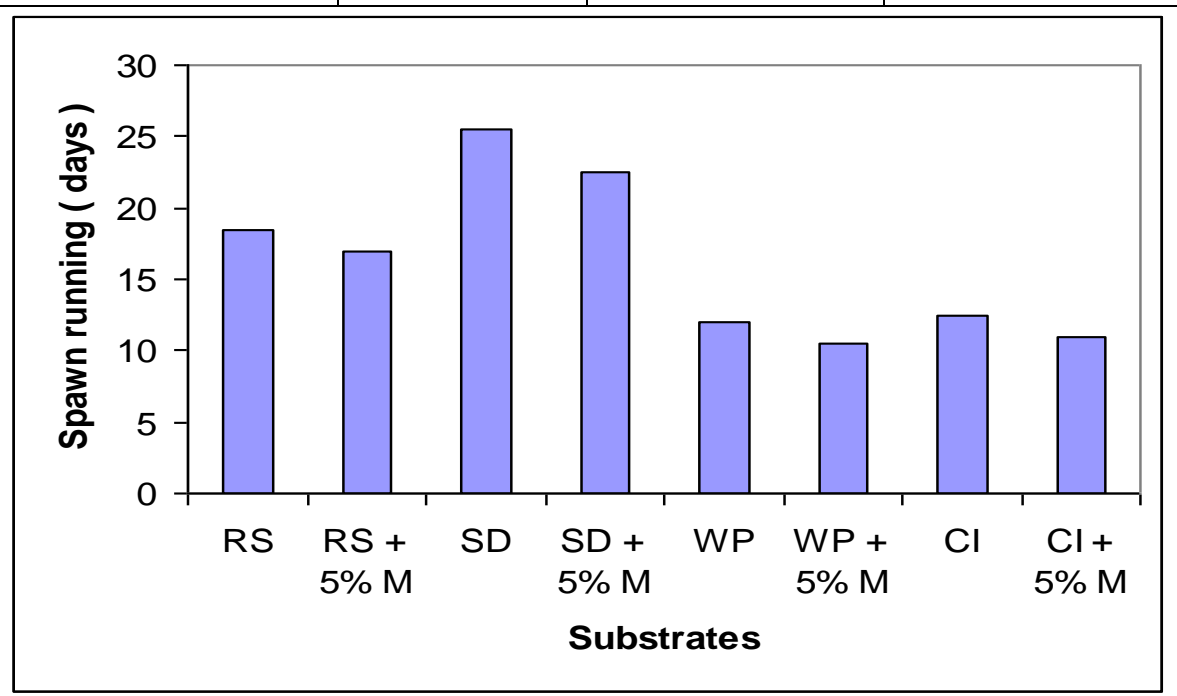

Fig 1: Effect of molasses on growth of $P$. ostreatus

RS ; Rice straw. SD; Sawdust. WP; Waste paper. Cl; Cardboard industrial. RS $+5 \% \mathrm{M}$; Rice straw + 5\% Molasses. SD +5\%M ; Sawdust + 5\% Molasses. WP + 5\%M ; Waste paper $+5 \%$ Molasses. $\mathrm{Cl}+5 \% \mathrm{M}$; Cardboard industrial $+5 \%$ Molasses.

\section{Yield and biological efficiency :}

Biological efficiency was calculated as the percentage yield of fresh mushroom fruiting bodies in relation to dry weight of the substrate. Biological efficiency was calculated because some substrates were denser than others (Akyuz and Yildiz, 2008).

Analyses of oyster mushroom yield revealed significant differences $(P<0.05)$ between used substrates (Table 4$)$. Rice straw was superior to all the other substrates. Tested agro-industrial wastes recorded various flushes. 
The first flush of crop gave $50 \%$ of the yield obtained in all the by-product substrates tested. Yield of $P$. ostreatus and biological efficiency on different substrates. Data on the quantity of sporophores harvested in different flushes are presented in (Table 5).

The highest total weight of mushroom harvested per $1 \mathrm{~kg}$ dry substrate was recorded on rice straw $\sim 652.38 \mathrm{~g}$, followed by sawdust $\sim 251.20 \mathrm{~g}$, and the lowest yield was recorded on waste paper and cardboard. The biological efficiency of $P$. ostreatus production varied in different used substrates (Table 5 ). The maximum biological efficiency of $65.24 \%$ was recorded with rice straw, followed by sawdust $25.12 \%$.

Table 4. Analysis of variance of the effect of different substrates on Yields of $P$. ostreatus and Biological efficiency.

\begin{tabular}{|l|c|c|c|c|}
\hline \multicolumn{1}{|c|}{ Source } & Df & SS & MS & F- value \\
\hline Substrates & 3 & 775649.19 & 258549.73 & $14281.88^{*}$ \\
\hline (Error) & 12 & 217.24 & 18.103 & \\
\hline
\end{tabular}

${ }^{*}$ Indicate $\mathrm{P}<0,05$

Table 5. Effect of different substrates on Yields of $P$. ostreatus and Biological efficiency.

\begin{tabular}{|l|c|c|}
\hline \multicolumn{1}{|c|}{ Substrates } & $\begin{array}{c}\text { Total fresh weight of fungus } \\
\text { g/kg substrate dry weight }\end{array}$ & $\begin{array}{c}\text { Biological efficiency } \\
\% \text { ) }\end{array}$ \\
\hline Rice straw & 652.38 & 65.24 \\
\hline Sawdust & 251.20 & 25.12 \\
\hline Wast paper & 112.14 & 11.21 \\
\hline Cardboard industrial & 117.93 & 11.83 \\
\hline LSD at 5\% & 6.558 & 0.655 \\
\hline
\end{tabular}

Effect of molasses on yield and biological efficiency :

The aim of the present study was to determine the yield performance of added molasses for cultivation on agro-industrial wastes product of oyster mushroom. Molasses has high carbohydrates such as sucrose, glucose and fructose. It seems that the carbon source is more necessary as an energy source than protein sources for fruiting formation. (Yang et al., 2003).

The analysis of the variance effect of molasses on oyster mushroom yield showed significant differences $(P<0.05)$ between used substrates (Table 6).

Table 6. Analysis of variance the Effect of molasses on yield of $P$. ostreatus and Biological efficiency.

\begin{tabular}{|l|c|c|c|c|}
\hline \multicolumn{1}{|c|}{ Source of variance } & DF & SS & MS & F- value * \\
\hline Substrates & 3 & 939460.06 & 313153.35 & 3572.77 \\
\hline (Error) & 12 & 1051.82 & 87.65 & \\
\hline
\end{tabular}

* Indicate $\mathbf{P}<0.05$ 
The effect of molasses on yield performance of $P$. ostreatus was shown in (Table 7). The application of $5 \%$ molasses provide by the highest yield compared to the other treatments. The highest yield was obtained by in substrates added with $5 \%$ molasses to rice straw (RS) followed by sawdust (SD) being $717.50 \mathrm{~g}$ and $276.35 \mathrm{~g}$ respectively. Also, the maximum biological efficiency $(71.75 \%$ ) was obtained on rice straw (RS ) followed by sawdust (SD) molasses treatments ( $27.64 \%$ ). So, it could be stated that. Molasses significantly increased biological efficiency over control substrates at the ratio ranged from rate $1.13-6.51 \%$ ( Fig 2 ).

Table 7. Effect of molasses on yield of $\boldsymbol{P}$. ostreatus and Biological efficiency.

\begin{tabular}{|l|c|c|}
\hline $\begin{array}{c}\text { Substrates containing 5\% } \\
\text { molasses }\end{array}$ & $\begin{array}{c}\text { Total fresh weight of fungus } \\
\text { g/kg substrate dry weight }\end{array}$ & $\begin{array}{c}\text { Biological efficiency } \\
(\%)\end{array}$ \\
\hline Rice straw & 717.50 & 71.75 \\
\hline Sawdust & 276.35 & 27.64 \\
\hline Waste paper & 123.38 & 12.34 \\
\hline Cardboard industrial & 129.60 & 12.96 \\
\hline LSD at 5\% & 14.431 & 1.443 \\
\hline
\end{tabular}

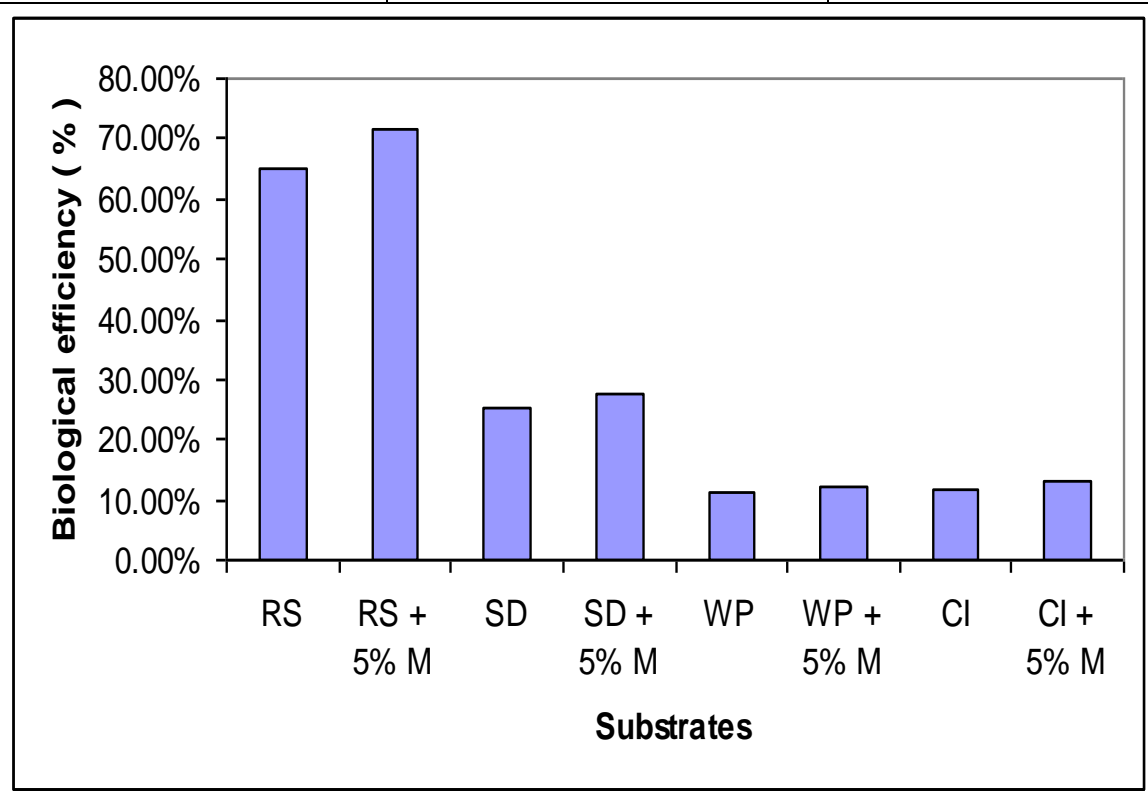

Fig 2 : Effect of molasses on biological efficiency of P.ostreatus

RS ; Rice straw. SD; Sawdust. WP; Waste paper. Cl; Cardboard industrial. RS + $5 \% \mathrm{M}$; Rice straw $+5 \%$ Molasses. SD $+5 \% M$; Sawdust $+5 \%$ Molasses. WP $+5 \% M$; Waste paper $+5 \%$ Molasses. $\mathrm{Cl}+5 \% \mathrm{M}$; Cardboard industrial $+5 \%$ Molasses. 
This results are in agreement with those reported by Erkel, (2009) in their Yield performance of Ganoderma lucidum (Fr.) Karst cultivation on substrates containing different protein and carbohydrate sources

\section{REFERENCES}

Akyüz, M. and A. Yildiz (2008). Evaluation of cellulosic wastes for the cultivation of Pleurotus eryngii (DC. ex Fr.) Quel. African Journal of Biotechnology Vol. 7 (10) : $1494-1499$.

Baker, P. (1979). Proc. AFMA Ninth Ann. Liquid Feed Symp. Amer. Feed Manufacturers Assoc. Arlington, VA

Beetz, A. and M. Kustudia (2004). Mushroom cultivation and marketing. Horticulture production guide (www.attra.ncat.org)

El-Sawah, M. M. A. (2000). How to cultivation mushroom. Dar El-Nile, Printing Publication, Mansoura, Egypt.

Erkel, E. (2009). Yield performance of Ganoderma lucidum (Fr.) Karst cultivation on substrates containing different protein and carbohydrate sources. African Journal of Agricultural Research Vol. 4 (11) : 1331 1333.

Espindola, L. H. S., F. S. Espindola, G. R. Freitas and M. A. M. Brandeburgo (2007). Biodegradation of red 40 dye by the mushroom Pleurotus sp. Florida. Biosci, J., 23: 90 - 93.

Hsieh, C., T. H. Hsu and F. C. Yang (2005). Production of polysaccharides of Ganoderma lucidum. Process. Biochem. 40(2) : $909-916$.

Kulshreshtha, S., N. Mathur, P. Bhatnagar and B. L. Jain (2010). Bioremediation of industrial waste through mushroom cultivation. Journal of Environmental Biology. 31: $441-444$.

Mandeel, Q. A., A. A. Al-Laith and S. A. Mohamed (2005). Cultivation of oyster mushrooms (Pleurotus spp.) on various lignocellulosic wastes. World J Microbiol Biotechnol 4 : $601-607$.

Paterrson-Beedle, M., J. Kennedy, F. A. D. Melo, L. L. Lloyd and V. Medeiros (2002). A cellulosic expolysaccharide produced from sugarcane molasses by a Zoogloea sp. Carbohydr. Polym. 42 : $375-383$.

Ragunathan, R. and K. Swaminathan (2003). Nutritional status of Pleurotus spp. grown on various agro-wastes. Food Chemistry 80: 371-375.

Shah, Z. A., M. Ashraf and M. Ishtiaq Ch (2004). Comparative Study on Cultivation and Yield Performance of Oyster Mushroom (Pleurotus ostreatus) on Different Substrates (Wheat Straw, Leaves, Saw Dust) Pakistan Journal of Nutrition 3 (3) : $158-160$.

SPSS (1999). SPSS 10 for Windows. SPSS, Chicago,III.

Yang, F. C., C. Hsieh and H. M. Chen (2003). Use of stillage grain from a ricespirit distillery in the solid state fermentation of Ganoderma lucidum. Process. Biochem. 39(1) : $21-26$. 


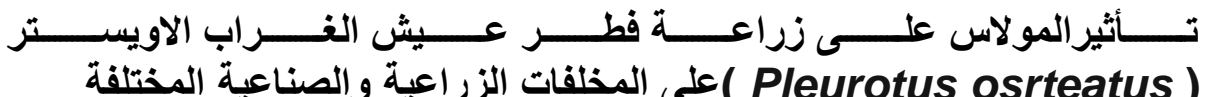

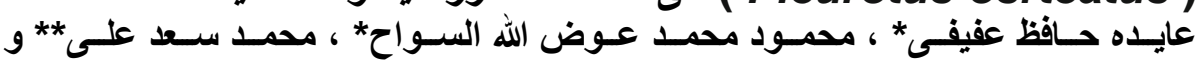

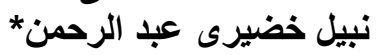

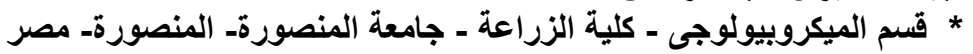

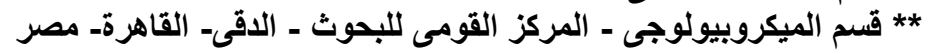

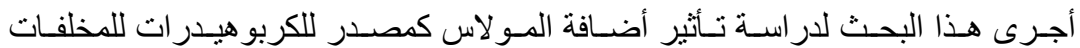

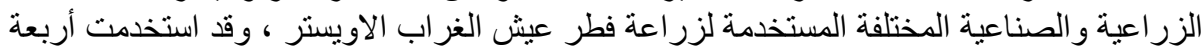

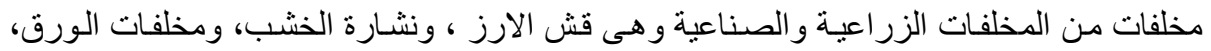
وورق الكرنون الصناعى لزر اعة النوع بليروتس اوستريتش

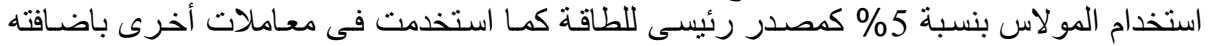

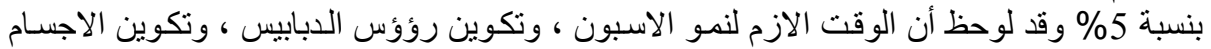

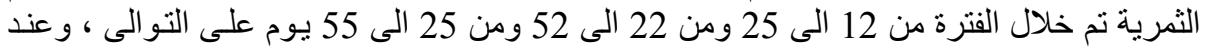

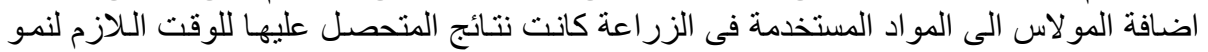

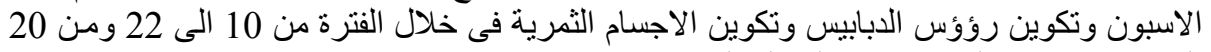

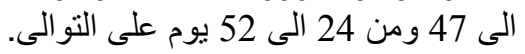

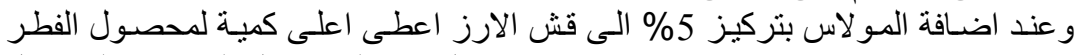

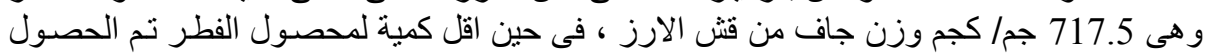

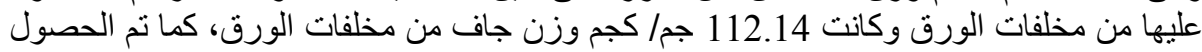

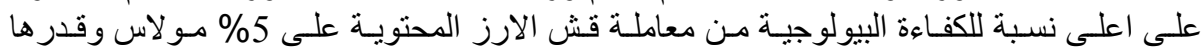

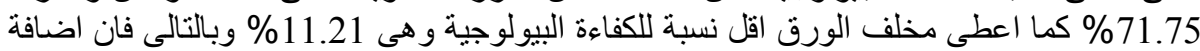

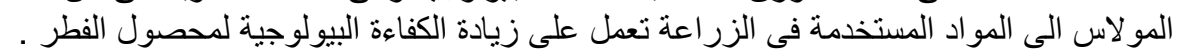

كلية الزراعة - جامعة المنصورة

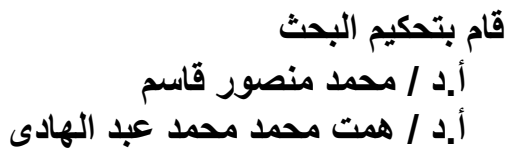
كلية الزراعة - جامعة - جامعة عين شمس لمس 